\title{
Nanoparticles in relation to peptide and protein aggregation
}

This article was published in the following Dove Press journal:

International Journal of Nanomedicine

12 February 2014

Number of times this article has been viewed

\author{
Masihuz Zaman \\ Ejaz Ahmad \\ Atiyatul Qadeer \\ Gulam Rabbani \\ Rizwan Hasan Khan \\ Interdisciplinary Biotechnology \\ Unit, Aligarh Muslim University, \\ Aligarh, India
}

Correspondence: Rizwan Hasan Khan Interdisciplinary Biotechnology Unit, Aligarh Muslim University, Aligarh-202002, Uttar Pradesh, India

Tel +9l 57| 2720388

Fax +9| 57| 272 I776

Email rizwanhkhan@hotmail.com

\begin{abstract}
Over the past two decades, there has been considerable research interest in the use of nanoparticles in the study of protein and peptide aggregation, and of amyloid-related diseases. The influence of nanoparticles on amyloid formation yields great interest due to its small size and high surface area-to-volume ratio. Targeting nucleation kinetics by nanoparticles is one of the most searched for ways to control or induce this phenomenon. The observed effect of nanoparticles on the nucleation phase is determined by particle composition, as well as the amount and nature of the particle's surface. Various thermodynamic parameters influence the interaction of proteins and nanoparticles in the solution, and regulate the protein assembly into fibrils, as well as the disaggregation of preformed fibrils. Metals, organic particles, inorganic particles, amino acids, peptides, proteins, and so on are more suitable candidates for nanoparticle formulation. In the present review, we attempt to explore the effects of nanoparticles on protein and peptide fibrillation processes from both perspectives (ie, as inducers and inhibitors on nucleation kinetics and in the disaggregation of preformed fibrils). Their formulation and characterization by different techniques have been also addressed, along with their toxicological effects, both in vivo and in vitro.
\end{abstract}

Keywords: amyloid formation, inducer, inhibitor, nanoparticle, nucleation, toxicity

\section{Introduction}

Nanoparticles are nanosized materials with a dimension of 1-100 $\mathrm{nm}$. These particles exhibit interesting optical, electronic, and catalytic properties, which are very different from those of the corresponding bulk materials. Nanoparticles can be naturally found in the atmosphere, primarily in natural waters, soils, and sediments. Both natural and synthetic nanoparticles have practical applications in a variety of areas, ranging from environmental remediation to an emerging multidisciplinary field that combines chemistry, engineering, physics, biology, and medicine (Figure 1). ${ }^{1}$ Nanoparticles are expected to bring about a revolution for the inhibition of protein and peptide aggregation - a process related to several "misfolding diseases."

Proteins are important biological macromolecules that are fundamental to the proper functioning of cells and organisms; therefore, the impact of nanoparticles in living organisms at the protein level is a critical issue that is attracting increasing attention from researchers. Protein and peptide aggregation into characteristic amyloid fibrils is a major cause of various neurodegenerative diseases like Alzheimer's, Parkinson, Creutzfeldt-Jakob disease, and others., ${ }^{2,3}$ In such diseases, there is a conversion of proteins or peptides from their soluble functional states to highly organized fibrillar aggregates. ${ }^{3}$ Altogether, the accumulation of abnormal protein and peptide aggregates 


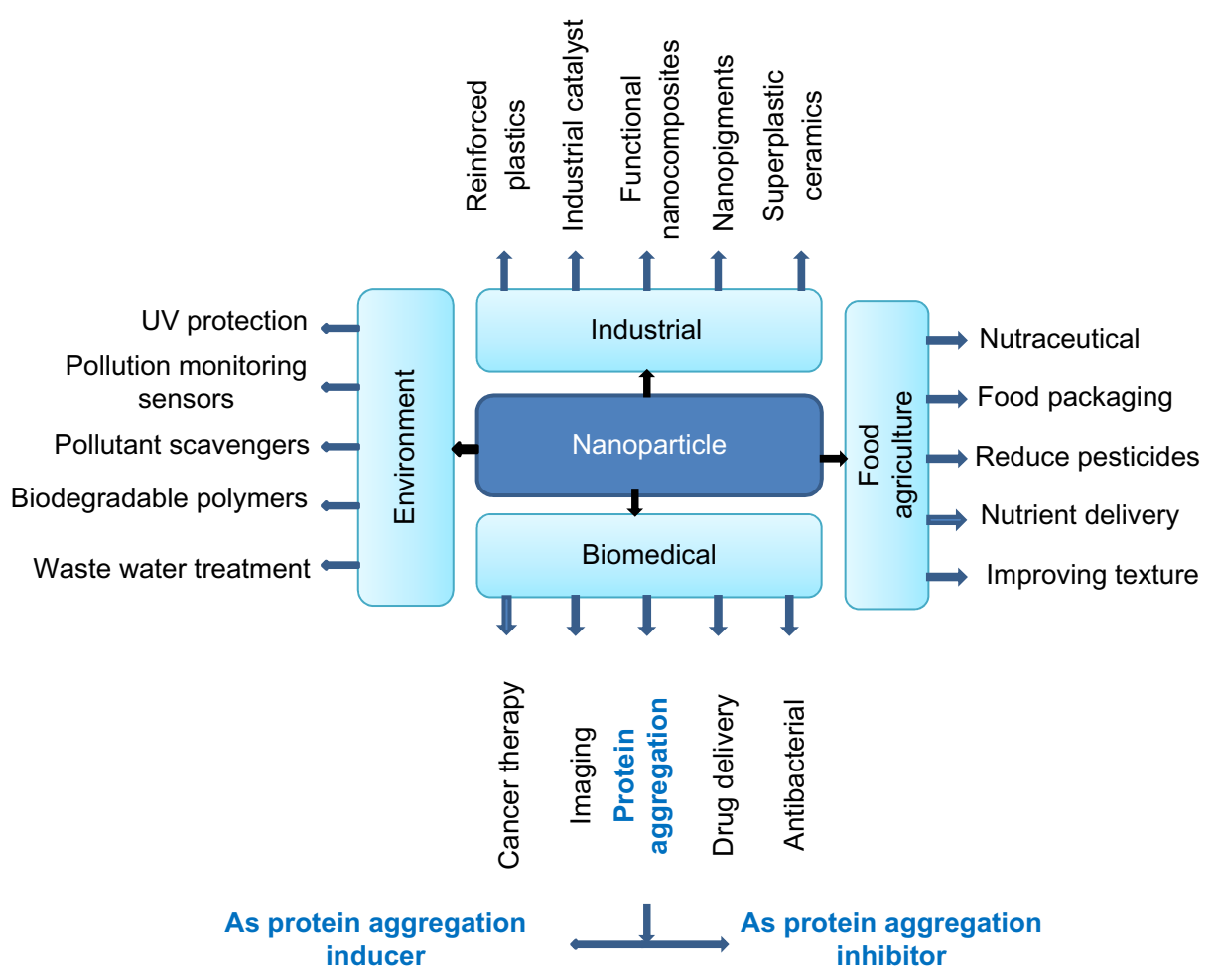

Figure I Application of nanoparticles in various fields such as in the biomedical, environmental, industrial, and food agriculture industries. Abbreviation: UV, ultraviolet.

exerts toxicity by disrupting intracellular transport, overwhelming protein degradation pathways, and/or disturbing vital cell functions. In addition, the formation of inclusion bodies is known to represent a major problem in the recombinant production of therapeutic proteins and peptides. ${ }^{4} \mathrm{On}$ the other hand, amyloids also hold biological importance, as positive physiological activity (like human Pmel17) has an important role in the biosynthesis of pigment melanin, and factor XII protein of the homeostatic system is activated by amyloid formation. ${ }^{5}$ Amyloid fibril formation proceeds through nucleated growth mechanism, and the conversion of a peptide or a protein into its fibrillar form (measured by different techniques) includes a lag phase followed by an exponential phase. ${ }^{6,7}$ It is the lag phase in which nuclei form and further monomers or oligomers are associated in the fibrillation of proteins. The fibrillation behavior can be modulated by several factors including hydrophobicity, types of secondary structures, the presence of chaperons, peptide inhibitors, as well as solution properties such as ionic strength, $\mathrm{pH}$, temperature, and so on. ${ }^{8,9}$ Thermal denaturation leads to the exposure of hydrophobic residue, which increases hydrophobic attraction that overcomes electrostatic repulsion, and triggers the aggregation of amorphous aggregates. Hill et $\mathrm{al}^{10}$ found that net attraction causes precipitation, while interaction of repulsive charges causes amyloid formation.
Recently Raccosta et al, ${ }^{11}$ working on lysozyme aggregation, clearly indicated that at low $\mathrm{pH}$ and low ionic strength, a lysozyme solution is thermodynamically stable in both its native and denatured state (Figure 2). Formation of amyloid occurs not only at higher temperatures, where proteins undergo partial unfolding, but also at $\mathrm{pH}$ levels far from their isoelectric point where proteins are electrically charged. ${ }^{12,13}$ It has been shown that modified surfaces of lipid bilayers, collagen fibers, liquid air, liquid-solid, or liquid-liquid interfaces have specific and significant effects in promoting amyloid formation. ${ }^{14,15}$ Nanoparticles possess an enormous surface area and are found to influence the amyloid-forming behavior of proteins very controversially. The interaction of nanoparticles with proteins can affect both protein structure and function; ie, they can inhibit or facilitate amyloid formation.

The experimental data showed that copolymer particles, cerium oxide particles, carbon nanotubes, and quantum dots enhance the rate of fibril formation from $\beta 2$ microglobulin by decreasing the lag time for nucleation. ${ }^{16}$ It was observed that the duration of the lag phase depends upon the amount and nature of the particle surface. Wu et al ${ }^{17}$ observed that titanium oxide nanoparticles promote $\mathrm{A} \beta$ peptide amyloid aggregation, and in these types of cases, nanoparticles may act as catalysts for amyloid assembly. The molecular events behind the processes beginning from the native to fibrillar 


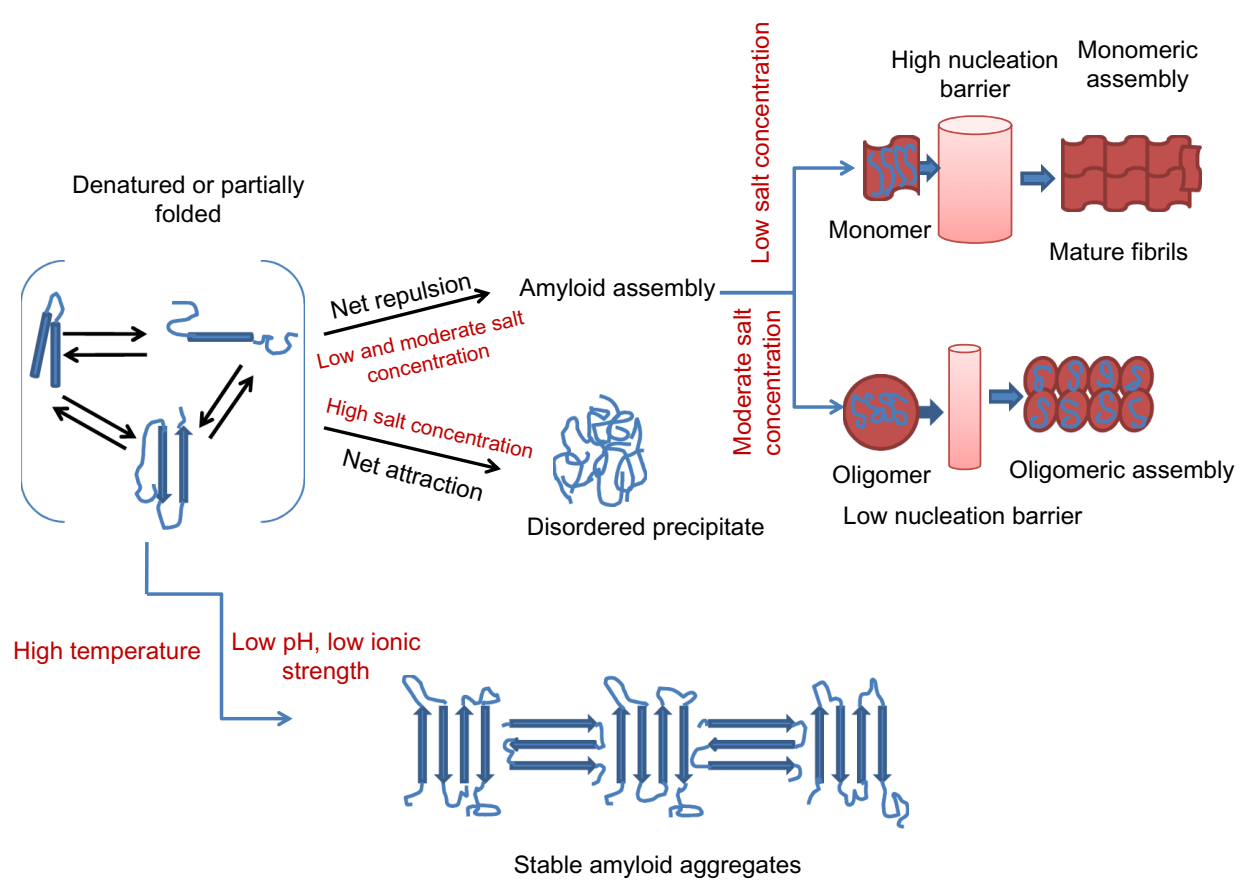

Figure 2 Effect of salt, $\mathrm{pH}$, and temperature on protein aggregation.

Note: Low and moderate salt concentrations cause amyloid assembly, while a high salt concentration is responsible for disordered precipitates.

state remain elusive, but the data from many studies suggest that fibrillation involves a number of intermediate oligomeric states of different association numbers and structures. ${ }^{18}$ Engineered nanoparticles may be an effective strategy for inhibiting the fibrillation of proteins at its various stages, while keeping in mind safety issues such as biocompatibility and biodegradability.

In the present review, we explored nanoparticle effects on protein fibrillation from both perspectives (ie, as an inducer and an inhibitor), their preparation, characterization, and toxicity (both in vivo and in vitro). We also highlighted some peptide and protein nanoparticles with their unique functionalities and potential applications.

\section{Characteristics of nanoparticles}

Synthetic nanoparticles include polymer conjugates, polymeric nanoparticles, lipid-based carriers such as liposomes and micelles, dendrimers, carbon nanotubes, peptides, and gold nanoparticles, including nanocages. ${ }^{19}$ Owing to their high surface area-to-volume ratio, it is possible to achieve high ligand density on the surface for targeting purposes. In terms of composition, nanoparticles are comprised of mainly two parts: the core material and the surface modifier that may be engaged to change the physiochemical properties of the former. ${ }^{20}$ Changes in protein conformation upon binding with nanoparticles, or increased local protein concentration on the nanoparticle surfaces could promote aggregation, while trapping of early aggregation intermediates may inhibit further aggregation. ${ }^{21}$ Nanoparticles possess huge amounts of Gibb's free energy, which enhances their adsorption capacities. The conjugation of proteins to nanoparticles not only stabilizes the system, but also introduces biocompatible functionalities to these particles for further biological interactions or coupling. ${ }^{22,23}$ Nanoparticles also offer the benefit of carrying functional groups (amino and carboxylic groups), which can be used for surface modification. ${ }^{24}$ On the other hand, nanoparticles possess higher stability during storage, in vivo stability after administration, as well as being easily adjustable during preparation. ${ }^{25}$

\section{Peptide nanoparticles and their conjugates}

Peptide nanoparticles offer several unique advantages that make them attractive for therapeutic applications. Their smaller size minimizes the overall radius of the resulting peptide nanoparticle conjugate, while still affording high valance (ie, the number of peptides per nanoparticle). ${ }^{26}$ Apart from this, their size reduces immunogenicity in vivo, and their production is economical and facile. Peptide nanoparticles are biocompatible, derived from naturally occurring protein precursors, and can be very specific; they also bind tightly to the receptors. ${ }^{27}$ Based on the structural features of amyloid fibrils and the mechanism of their assembly, several peptides and their analogs have been designed and 
synthesized towards various protein aggregation diseases. Pentapeptides, like KLVFF (Lys-Leu-Val-Phe-Phe) and LVFFA (Leu-Val-Phe-Phe-Ala) are widely used as binding elements to design inhibitors of fibrillation as they mimic some residues in the hydrophobic core of $A \beta 1-40$ fibrils. ${ }^{28}$ LV (Leu-Phe) and VF (Val-Phe) peptides containing leucine and valine residues, respectively, in the hydrophobic core region provide an attractive tool for capturing the toxic $\mathrm{A} \beta$ 1-42 aggregates in Alzheimer's disease. ${ }^{29}$ In this process, soluble oligomers that are responsible for this disease, and the small amounts of mature A $\beta$ 1-42 fibrils, are transformed into peptide fibrils. However, a novel strategy was reported by Li et $\mathrm{al}^{30}$ for inhibition of amyloid beta peptide aggregation by polyoxometalate-peptide hybrid particles. ${ }^{30}$ The authors reported that self-assembly of these peptide hybrids is effective against $A \beta$ inhibitors. Various small peptides called $\beta$-sheet breakers are effective against the process of beta-amyloid fibrillation by dissolving amyloid fibrils in vivo as well as in vitro. Jarmula and Stepkowski ${ }^{31}$ reported two $\beta$-sheet breakers iA $\beta 5$ (LPFFD) and iA $\beta 6$ (LPFFFD), which have two to three consecutive Phe residues that are responsible for forming a stacked conformation. Apart from this, cyclic peptides have great potential to be therapeutic agents against many debilitating amyloid-related diseases. One example of this type of peptide was reported by Todorova et al;32 this peptide, cyc (60-70), is derived from human apolipoprotein CII, which acts against amyloid formation by the fibrillogenic peptide, apoC-II (60-70). Liu et $\mathrm{al}^{33}$ explored a B6 peptide in conjugation with polyethylene glycol-polylactic acid nanoparticles to enhance the delivery of neuroprotective drugs across the blood-brain barrier for the treatment of Alzheimer's disease. These modified conjugates show higher accumulation in brain capillary endothelial cells via lipid raft-mediated and clathrin-mediated endocytosis. ${ }^{33}$

\section{Protein nanoparticle and their conjugates}

Due to their defined structure and biodegradable nature, protein-based nanoparticles provide large possibilities for surface alterations and for the covalent attachment of drugs and ligands. ${ }^{34}$ In addition, they are nontoxic and easy to crosslink, they can be easily modified and sterilized, are usually not contaminated with pyrogens, and generally possess low antigenicity. ${ }^{35}$ Gelatin, albumin, gliadin, legumin, zein, and soy are some proteins that are commonly used for nanoparticle formulations. Gelatin is obtained by controlled hydrolysis of fibrous, insoluble proteins, and by collagen, which is widely found as the major component of skin, bones, tendons, and connective tissue. ${ }^{36}$ The mechanical properties, swelling behavior, and thermal properties depend significantly on the degree to which gelatin crosslinks. ${ }^{37}$ Gelatin has either a positive or negative charge depending upon the type of amino acids residues. Formation of type 1 and type 2 gelatin depends upon the treatment of collagen with an acid and base, respectively. Glycine, proline, and alanine are present in gelatin, and these elements are responsible for the formation of gelatin's triple-helix structure. They also provide great flexibility for modification and covalent attachments, and further modification takes place on the particle's surface or in the matrix of the particle. ${ }^{38,39}$

Recently, Kuntworbe and Al-Kassas ${ }^{40}$ developed cryptolepine hydrochloride-loaded gelatin type A nanoparticles that provide a better approach in the treatment of malaria. Zein, a prolamine protein obtained from maize with threefourths lipophilic amino acid residues and one-fourth hydrophilic amino acid residues, provides unique aqueousalcohol solubility, as well as contributes to its film-forming property. It is widely used for nanoparticle preparation in food and nutraceutical industries, and for encapsulating lipophilic bioactive compounds. For nutraceutical and drug encapsulation, one of the most widely utilized proteins is soy protein. ${ }^{41}$ The soy protein isolate-enriched form of soy protein possesses a balanced composition of polar, non-polar, and charged amino acids, ${ }^{41}$ which can incorporate ligands through its various functional groups. This protein is beneficial in pharmaceutics, because it can help to design an appropriate drug against various protein aggregation diseases, which may be due to polar, non-polar, or charged amino acid residues. ${ }^{41}$ For the formation of mucoadhesive nanoparticles, another protein, gliadin (which is obtained from the gluten of wheat and vicillin, and which is rich in lipophilic and neutral amino acids), appears to be a suitable polymer in the formulation industry. ${ }^{42}$

Among all of the proteins, albumin is an attractive macromolecule that has been shown to be biodegradable, nontoxic, metabolized in vivo to produce innocuous degradation products, available in pure form, non-immunogenic, and soluble in water; it makes an ideal candidate for nanoparticle formulation. ${ }^{43}$ Albumins are of different types like ovalbumin, human serum albumin, bovine serum albumin, and so on. Due to define primary structure and high content of charged amino acid residues, albumin-based nanoparticles could allow for the electrostatic adsorption of positivelyand negatively-charged molecules without the requirement of other compounds. ${ }^{44,45}$ Apart from this, they can be easily prepared under normal environmental conditions by various methods like coacervation, controlled desolvation, and emulsification. In addition, albumin nanoparticles are well 
tolerated by our body, which is supported by various clinical trials on registered human serum albumin-based particle formulation like Albunex ${ }^{45}$ (Mallinckrodt Pharmaceuticals, Hazelwood, MO, USA) and Abraxane ${ }^{\circledR 46}$ (Celgene Corporation, Summit, NJ, USA).

\section{Preparation methods}

Currently, there are various methods that are being used for the preparation of nanoparticles. Several comprehensive reviews are available where the preparatory methods are discussed in great detail. ${ }^{47-49}$ The commonly employed materials and methods used for the synthesis of nanoparticles are summarized in Table 1. Protein-based nanoparticles, such as those that use albumin, gliadin, legumin, and so on, are synthesized by an emulsification method in which phase separation is required by addition of a desolvating agent, followed by modifications in temperature as well as $\mathrm{pH} .{ }^{50-54}$ Nanoparticles synthesized from metals such as gold, copper, and silver, are synthesized using the citrate synthetase method. Gold nanoparticles are synthesized by the reduction of chloroauric acid using trisodium citrate in the presence of a stabilizing agent; however, copper nanoparticles are synthesized by the reduction of copper salts by sodium citrate and myristic acid. ${ }^{55,56}$ Silver nanoparticles are synthesized by the method described by Bae et al, ${ }^{57}$ as shown in Figure 3.
Among the organic compounds, poly(lactic-co-glycolic) acid is most popular in the synthesis of nanoparticles, as it controls the parameters using bottom-up and top-down techniques. ${ }^{58}$ For the preparation of nanoparticles from different inorganic nanomaterials such as metal oxides, alloys, chalcogenides, and pinctides, chemical methods are very useful. ${ }^{59}$ Recently, Wei et $\mathrm{a}^{60}$ reported various inorganic nanoparticles such as terbium, erbium, yttrium, zinc, gadolinium, and others, using a facile homogeneous precipitation method, and the authors found that these particles show low toxicity even at a concentration of $5 \mathrm{mg} / \mathrm{mL} .{ }^{60}$ Dendrimers are synthesized by two commonly used approaches (ie, convergent and divergent ${ }^{61}$ ), as described in Figure 4.

\section{Analytical techniques used for the characterization of nanoparticles}

When materials are reduced at nanoscale dimensions, they show unique properties that are different from their massive counterparts. In order to characterize nanoparticles in a solution, their particle size, size distribution, morphology, composition, surface area, surface chemistry, and reactivity are important factors that need to be defined accurately. These properties make nanomaterials a suitable carrier for unique sensing applications and, at the same time, they may also create complications during the characterization process.

Table I Standard methods for nanoparticle formulation using various techniques

\begin{tabular}{|c|c|c|c|c|}
\hline $\begin{array}{l}\text { Nanoparticle } \\
\text { material }\end{array}$ & Examples & $\begin{array}{l}\text { Methods that are } \\
\text { being used }\end{array}$ & Brief description & References \\
\hline \multirow[t]{2}{*}{ Protein } & Albumin & Emulsification method & $\begin{array}{l}\text { Phase separation in aqueous } \\
\text { media by addition of a } \\
\text { desolvating agent }\end{array}$ & 53 \\
\hline & Gelatin/legumin & Emulsification method & $\begin{array}{l}\text { Phase separation in aqueous } \\
\text { medium with modifications in } \\
\text { temperature and } \mathrm{pH}\end{array}$ & 54 \\
\hline \multirow[t]{3}{*}{ Metals } & Gold nanoparticles & Citrate synthesis method & $\begin{array}{l}\text { Reduction of chloroauric acid } \\
\text { using trisodiunm citrate }\end{array}$ & 55 \\
\hline & Copper nanoparticles & Citrate synthesis method & $\begin{array}{l}\text { Reduction of copper salt by } \\
\text { sodium citrate and myristic } \\
\text { acid }\end{array}$ & 56 \\
\hline & Silver nanoparticles & Citrate synthesis method & $\begin{array}{l}\text { Reduction of silver nitrate with } \\
\text { sodium citrate and sodium } \\
\text { borohydride }\end{array}$ & 57 \\
\hline Organic & PLGA nanoparticles & $\begin{array}{l}\text { Top-down and bottom- } \\
\text { up techniques }\end{array}$ & $\begin{array}{l}\text { Polymer is dissolved in organic } \\
\text { phase and further emulsified } \\
\text { with a suitable surfactant }\end{array}$ & 58 \\
\hline Inorganic & $\begin{array}{l}\text { Terbium, erbium, yttrium, zinc, } \\
\text { gadolinium, alloys, etcetera }\end{array}$ & $\begin{array}{l}\text { Facile homogeneous } \\
\text { precipitation method }\end{array}$ & $\begin{array}{l}\text { Zinc acetate dehydrate and } \\
\text { lanthanide nitrate salts are } \\
\text { used, as well as thiourea }\end{array}$ & 59,60 \\
\hline $\begin{array}{l}\text { Functional } \\
\text { groups }\end{array}$ & Dendrimer nanoparticle & $\begin{array}{l}\text { Divergent and convergent } \\
\text { approaches }\end{array}$ & $\begin{array}{l}\text { Reactive initiator is exposed } \\
\text { to appropriate reagents, which } \\
\text { results in branch assemblies }\end{array}$ & 61 \\
\hline
\end{tabular}

Abbreviation: PLGA, poly(lactic-co-glycolic acid). 


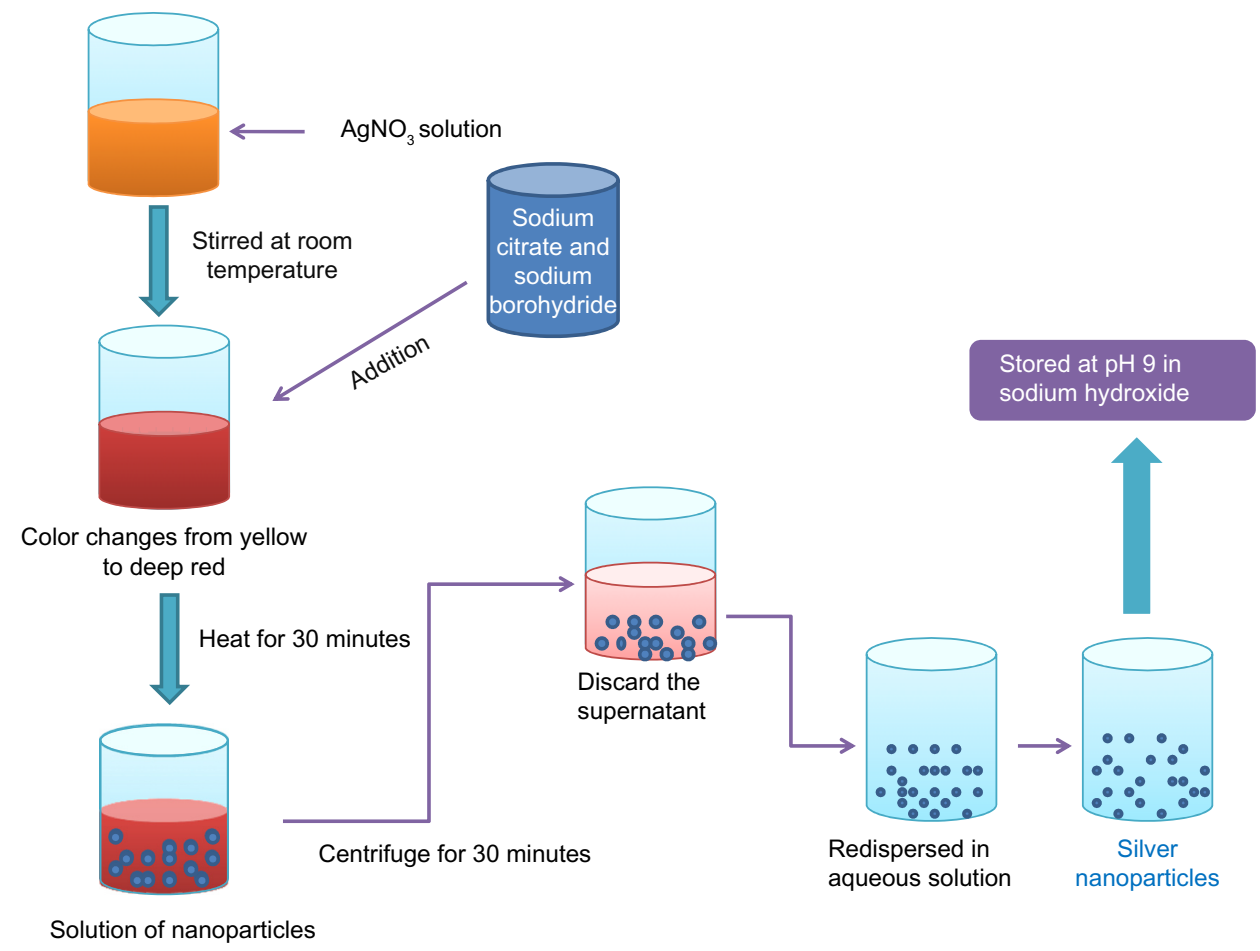

Figure 3 Preparation of silver nanoparticles using a citrate synthesis method.

Choosing the right method for the characterization of nanoparticles is a challenging task since one should be aware that each technique has its own limitations. The characterization of nanoparticles is carried out through various techniques like ultraviolet-visible spectroscopy, dynamic light scattering (DLS), scanning electron microscopy (SEM), transmission electron microscopy (TEM), X-ray diffraction analysis, thermo-gravimetric analysis, $\mathrm{X}$-ray photoelectron spectroscopy, and electrospray ionization mass spectroscopy (ESI-MS).

A
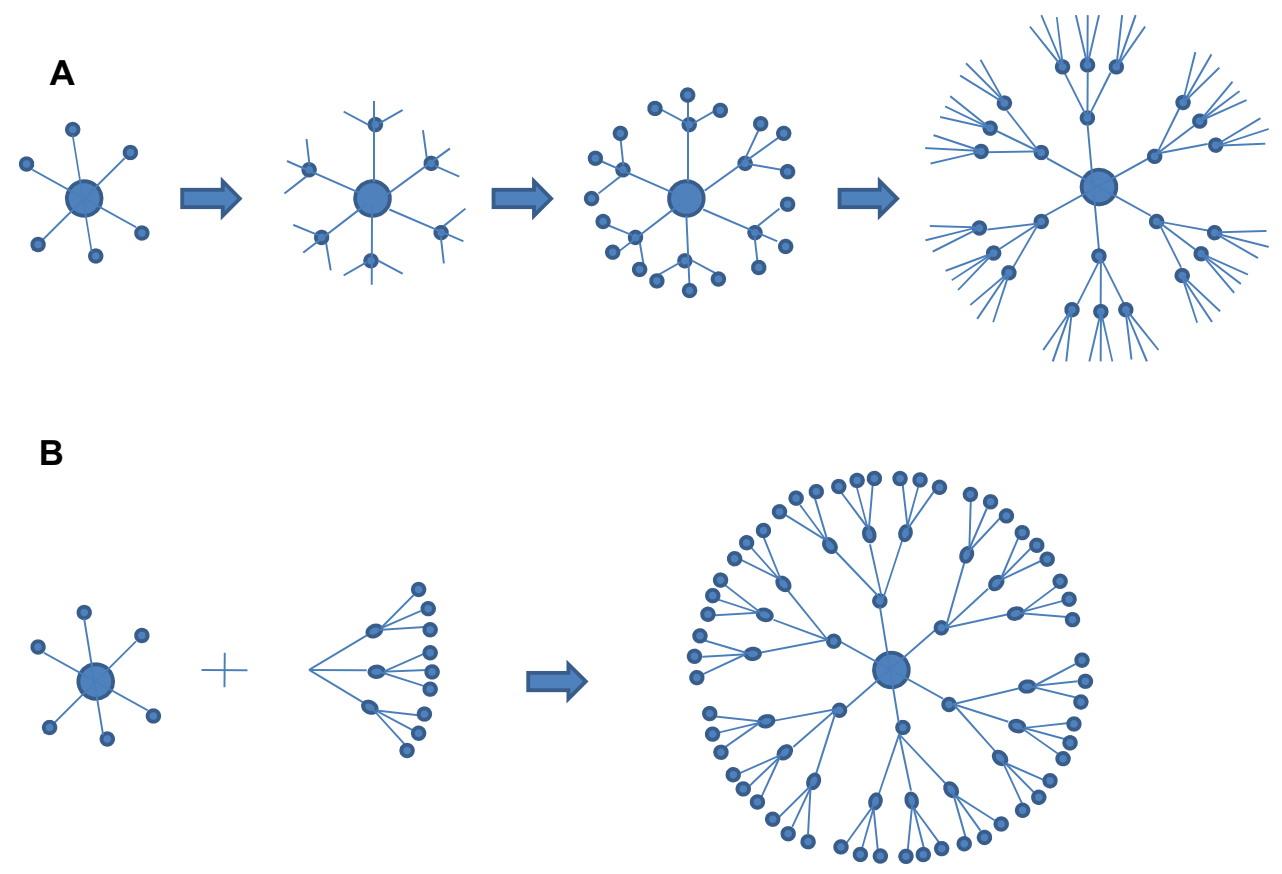

Figure 4 Different methods used in dendrimer formation. (A) Divergent and (B) convergent approaches for dendrimer preparation.

Notes: Adapted with permission from Crespo L, Sanclimens G, Pons M, Giralt E, Royo M, Albericio F. Peptide and amide bond-containing dendrimers. Chem Rev. 2005; 105(5): 1663-1681. ${ }^{61}$ Copyright (2005) American Chemical Society. 
The size of nanoparticles is one of the key parameters that influence the interaction between nanoparticles and proteins. Protein structure, function, and their adsorption patterns are also strongly influenced by the size of nanoparticles. Small sized particles have higher relative mobility in intracellular uptake, and they have a wider range of biological targets, when compared to microparticles, for disease diagnosis and treatment. Desai et al ${ }^{62}$ and Zauner et $\mathrm{al}^{63}$ showed that the size of nanoparticles influenced cellular uptake. Nanoparticle formulation with small size and maximum stability always pose a greater challenge, as described by Babaei et al. ${ }^{64}$ DLS is the most suitable technique to determine the particle size of nanoparticles. It can also be used to evaluate particle size, size distribution, and zeta potential in a solution. ${ }^{65}$ DLS is fast and easy to operate for particle characterization, especially for colloidal suspensions. There are several advantages associated with DLS: simplicity; sensitivity and selectivity to NPs; short time of measurement; and the fact that calibration is not needed. Therefore, this technique is increasingly used for nanoparticle characterization in various science and industry fields. ${ }^{66,67}$ However, some problems are encountered when measuring samples with larger size distributions or multimodal distributions. ${ }^{67}$ If the measured colloid is monodispersed, the mean diameter of the nanoparticles can be determined using the DLS technique. For polydispersed colloids, there is a risk during the DLS measurement, as small particles can be screened by bigger particles, since bigger particles have more scattering property.

Particle morphology is another important parameter for the characterization of nanoparticles, and this is achieved with the help of microscopic techniques like SEM and TEM. Both of these techniques produce a resolution that is a thousand times greater than the optical diffraction limit. SEM uses a beam of high-energy electrons to produce a variety of signals that contain information about the sample's surface composition, topography, and other properties like electrical conductivity. We can analyze the sample at various times because X-rays generated by SEM do not lead to a loss of volume of the sample. Magnification of approximately $10-500,000$ times can be obtained, and it is controlled by voltage supply to the $\mathrm{x}$, $\mathrm{y}$ deflector plates, or by supply of the current to the scanning coils. However, electron microscopy creates a risk of radiation damage that is caused by the electron beam, which leads to the generation of free radicals. The diffusion of free radicals and the loss of mass may cause physical damage to the sample. ${ }^{68}$ Also, TEM suffers from the limitations of poor contrast, especially in the event of peptide/ protein nanoparticles and their conjugates.
The chemical composition of the nanoparticulate surface can be detected by X-ray photoelectron spectroscopy. The underlying principle is that $\mathrm{X}$-rays strike the sample, which leads to the emission of photons at different energy levels for different elements.

The particle size of synthesized nanoparticles can also be characterized using ESI-MS. This technique is particularly suitable for analyzing the product mixtures, as it causes nearly no fragmentation of the different components. ESI uses electrical energy to assist in the transfer of ions from the solution into the gaseous phase before they are subjected to mass spectrometric analysis. Thus, ionic species, as well as neutral species (converted to ionic form in a solution or in the gaseous phase) can be studied by ESI-MS. ESI-MS also offers precise analysis of the core and shell composition of nanoparticles, as it alone gives the distribution of composition. More significantly, it also contributes to providing a deeper understanding of the nanoparticle's stability and reactivity and, thus, has obvious applications for control of the functionalization and biofunctionalization of nanoparticles. ${ }^{69,70}$

The most important aspect regarding nanoparticle characterization is the surface modification of the nanoparticle; its efficiency can be measured either by surface charge, an increase in surface hydrophobicity, or by the density of functional groups. The surface modification of the aqueous suspension containing the nanoparticles can be measured by determining its zeta potential. This reflects the particle electrical potential and is influenced by particle composition, as well as the medium in which the particle is dispersed. ${ }^{47}$ The zeta potential reflects colloidal stability, and this property can be influenced by the interaction between particles. Since most of the colloidal system is stabilized by electrostatic repulsion, the larger the repulsive forces, the less the chance that aggregates form. Normally, the zeta potential of the nanoparticles lies in the range between $-10 \mathrm{mV}$ to $+10 \mathrm{mV},{ }^{71}$ while the zeta potential of $<-30 \mathrm{mV}$ is considered as presenting with highly anionic character; moreover, a value $>+30 \mathrm{mV}$ depicts a highly cationic character (Table 2).

\section{Nanoparticle as a protein and peptide aggregation inducer}

Proteins are biologically important molecules in several respects. The binding of proteins in their native-like or denatured state depends on protein surface charge, hydrophobicity, intrinsic stability, and also on the particles' characteristics. When nanoparticles are introduced in a living organism, they interact with a variety of different cellular components 
Table 2 Characterization of nanoparticles by different techniques

\begin{tabular}{lll}
\hline Techniques & Parameters & Properties that are analyzed \\
\hline Dynamic light scattering & Hydrodynamic radius & Nanoparticle size, size distribution, and zeta \\
Photon correlation spectroscopy & Velocity distribution by measuring the & Nanoparticle average size, polydispersity index \\
& dynamic fluctuation of scattered light & analysis, etcetera \\
X-ray diffraction analysis & Diffraction pattern & Phase identification, nanoparticle structure, size, \\
X-ray photoelectron spectroscopy & Binding energy of the detected electrons & Nanoparticle composition, uniformity of composition \\
Laser doppler anemometry & Frequency shift and phase shift & Zeta potential and particle composition \\
Thermogravimetric analysis & Temperature and time as a function & Kinetic parameters, physical and chemical properties \\
Transmission/scanning electron & in mass change & Electron scattering \\
microscopy & & Morphology of particles, distribution of particles
\end{tabular}

with largely unknown pathological consequences. Various studies have concluded that the process of aggregation may be induced by nanoparticles through different mechanisms. Nanoparticles provide surface charges to promote the adherence of proteins, and their large surface area provides the potential to induce protein aggregation. However, this requires that the particle size be $<10 \mathrm{~nm}$, as it is reported that particles $>30 \mathrm{~nm}$ have no influence on protein adsorption. ${ }^{72}$ It is well known that fibrillation is a nucleation-dependent mechanism, and that nucleation is triggered by external factors. ${ }^{73}$ Nanoparticles act as catalysts to facilitate the subsequent assembly of peptides into stable fibril aggregates by increasing the local concentration of those peptides. ${ }^{74}$ Nanoparticles may act like conventional catalysts by reducing the energy barrier between fibril formations due to an increase in the population of prefibrillar aggregates. ${ }^{75}$ Nanoparticle surfaces can act as platforms for protein association, and this association induces significant changes in protein structure.

Further, low $\mathrm{pH}$ and high temperature lead to the unfolding of proteins, which ends with the formation of fibril like structures. ${ }^{76}$ High protein concentrations may lead to the formation of amyloid aggregates. This is illustrated by the fact that multiple layers of $\beta 2$-microglobulin, which are formed on the surface of $\mathrm{N}$-isopropylacrylamide/ $\mathrm{N}$-tert-butylacrylamide nanoparticles, as measured by surface plasmon resonance, clearly indicates that there must be a high local protein concentration that is favorable for the amyloid assembly. ${ }^{77}$ Particle shape also plays a significant role, as anisotropic particles (like single-walled carbon nanotubes) are well suited to anisotropic biomolecules, like deoxyribonucleic acid (DNA), as aggregation inducers. ${ }^{78}$ Another observation by Rocha et $\mathrm{al}^{79}$ showed that hydrogenated complexes promote $\beta$-sheet structures, leading to aggregation. The reduced zeta potential in hydrogenated complexes facilitates the interaction between peptide molecules, resulting in conversion of A $\beta 40$ from random coils to $\beta$-sheet structures. ${ }^{79}$ Very recently,
Jones et $\mathrm{l}^{80}$ demonstrated that fibrinogen, and other anionic blood proteins, undergo rapid and extensive aggregation by densely charged cationic $\mathrm{G} 7$ dendrimers through a thrombinindependent and cellular activation-free mechanism. The acidic nature of these proteins and their high concentration in blood predispose these elements to aggregation with oppositely charged dendrimers. ${ }^{80}$

\section{Nanoparticles as a protein and peptide aggregation inhibitor}

The primary strategies that are used to overcome neurodegenerative diseases are focused on inhibiting the self-assembly of proteins that are responsible for the fibril formation. The differences in the binding properties of oligomers and monomers can be exploited as a way to achieve this inhibition. Also, oligomers are considered to be the most neurotoxic species among $\mathrm{A} \beta$ agglomerates; their blocking by nanoparticles will be of great concern to the biological perspective. ${ }^{81}$ Various techniques (thioflavin T-binding assay, TEM, and surface plasmon resonance) are used to investigate the nanoparticle's ability to interact with proteins during fibrillogenesis. ${ }^{82,83}$ The interaction between thioflavin- $\mathrm{T}$ with amyloid fibrils causes a red shift in emission spectra, but no response is observed in the presence of soluble proteins, oligomers, or amorphous aggregates. ${ }^{82,83}$ Circular dichroism and photoluminescence are other important techniques that are used to investigate the inhibition of the fibrillation process, as these techniques provide a kinetic shift towards unfolded regions and make a clear distinction between protein secondary and tertiary structures ${ }^{84}$ Moreover, using a crystallographic model, Heldt et a ${ }^{85}$ provided the first evidence that insulin amyloid fibril formation occurs predominately unidirectionally, demonstrating that it may be asymmetric and propagate mostly in one direction.

In order to design an efficient inhibitor, as well as a nanomolecular species that is suitable for this purpose, 
there is a need to focus on the forces that are responsible for fibrillation. The interactions that are primarily involved in fibril formation are hydrophobic, electrostatic, van der Waals, as well as hydrogen bonding. ${ }^{86}$ Lee et al ${ }^{87}$ have demonstrated a three-stage kinetic model for amyloid formation, highlighting the molecular conformational properties that would be needed in order for inhibitors to bind to the nucleus or to other oligomers, so as to reduce their toxic effects. Inhibition by nanoparticles could be done at the nucleation phase (by increasing the lag phase), the polymerization phase (by decreasing the elongation phase), or via diversion of the peptide from the polymerization pathway to reduce the endpoint at equilibrium. Nanoparticles slow down the rate of fibrillation by altering the amount of free monomeric peptides that are present; yet, at the same time, fibril formation could not be prevented ${ }^{88}$ Experimental data show that nanoparticles added at the beginning of the kinetic experiment arrest the fibrillation process in lag phase. However, nanoparticles did not show any inhibitory effect when added after the control lag time (Figure 5). This indicates that once critical nuclei are formed, the elongation process is so favorable that the addition of nanoparticles does not have any effect on monomer/oligomer interactions with nanoparticles. ${ }^{88}$

High particle concentrations result in a strong interaction between peptides and nanoparticles (when present at the beginning or added later); this is enough to slow down the fibrillation process, probably by adsorption of the monomeric fibrils or initially formed oligomers. ${ }^{88}$ Once fibril formation has started, the addition of nanoparticles may reverse the process or destroy the fibrils. ${ }^{88}$ High protein concentrations lead to the formation of amyloid aggregates, but in some cases, high local protein concentrations inhibit fibril formation, as the interaction between nanoparticles and proteins leads to the blocking of active sites for fibril formation. ${ }^{89}$ Recently Skaat et al ${ }^{90}$ designed novel amino acid-based polymer nanoparticles (containing hydrophobic residues, similar to the hydrophobic core sequence of $A \beta$ ) and observed that polyA-FF-ME (poly(N-acryloyl-L-phenylalanyl-Lphenylalanine methyl ester)) nanoparticles affect the kinetics of nucleation and oligomer formation prior to the formation of $A \beta$ fibrils by increasing the fibrillation lag time. This could be explained on the basis that hydrophobic interactions, as pairs of FF residues, in these nanoparticles provide high affinity for the $A \beta 40$ prefibril aggregates, leading to a disruption in the nuclei by decreasing the concentration of monomers/oligomers in the solution, and thus interfering with the elongation process. ${ }^{90}$

Milowska et al ${ }^{91}$ investigated the effect of poly(amido amine) (PAMAM) G4 dendrimers on $\alpha$-synuclein, and they compared the structural changes in the presence of nanoparticles (dendrimers) with the help of circular dichroism. The
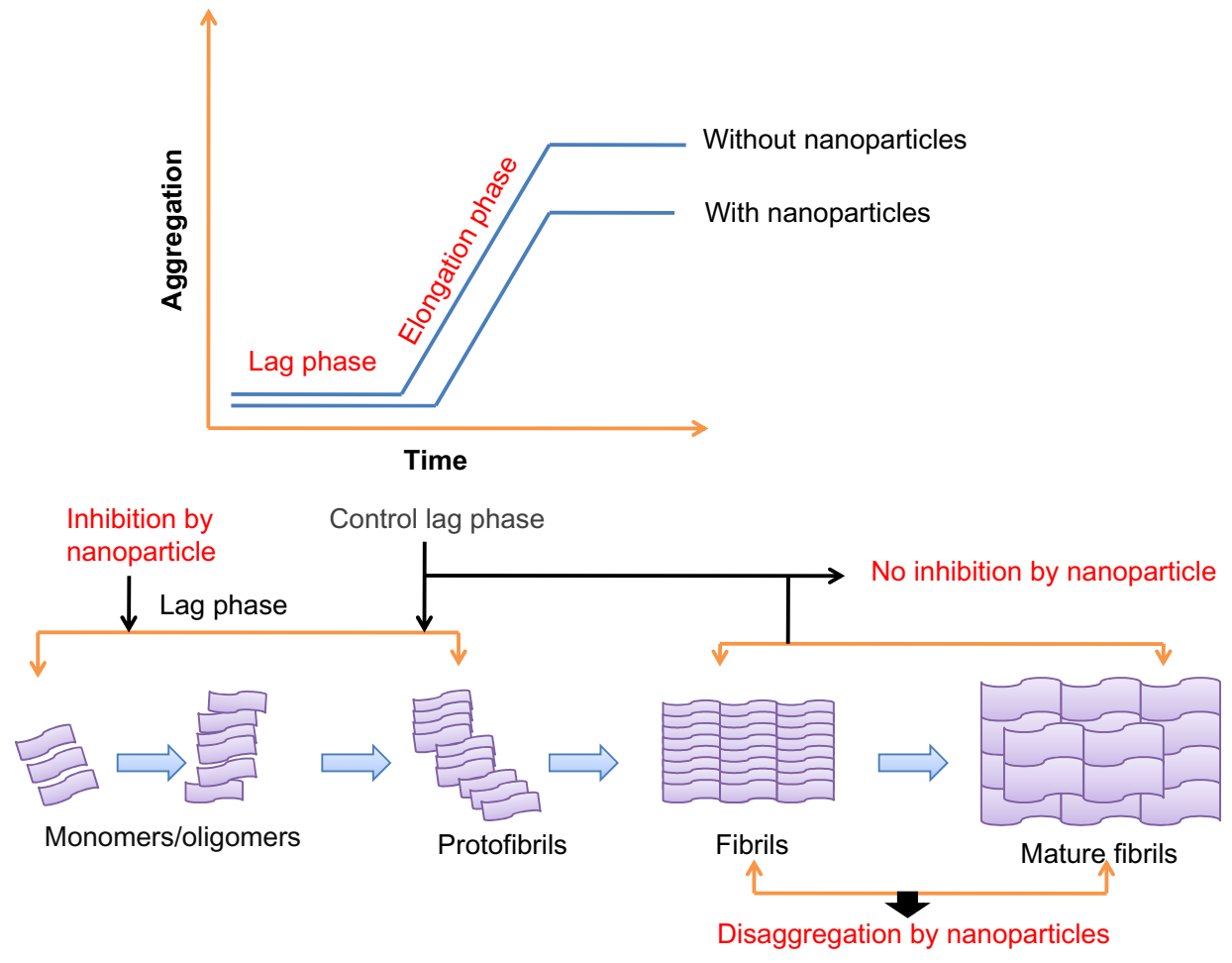

Figure 5 Effect of nanoparticles on nucleation kinetics.

Note: The addition of nanoparticles causes an increase in the lag phase and a decrease in the elongation phase. 
higher percentage of $\alpha$-structure, as well as the presence of a positive signal in the range of 195-206 $\mathrm{nm}$ after incubation with the nanoparticles, indicated that there was a reduction in the $\beta$-sheet structure. ${ }^{91}$ Dendrimer nanoparticles can be used as thermodynamic and kinetic inhibitors based on their size and concentration. ${ }^{92}$ In the case of kinetic inhibitors, the final amount of fibrils remained unchanged with the varying lag time, while thermodynamic inhibitors did not affect the amyloid formation rate; however, with the thermodynamic inhibitors, the final amount of fibrils was reduced. Lower generation (ie, G3) PAMAM dendrimers have a clear influence on the elongation rate of $A \beta$ aggregation - an effect that is less pronounced for the higher generation $(\mathrm{G} 4, \mathrm{G} 5)$. Rekas et $\mathrm{al}^{93}$ investigated the effect of PAMAM dendrimers on $\alpha$-synuclein during the fibrillation and decomposition of preformed fibrils, and found that dendrimers act as inhibitors in the formation of the $\beta$-sheet structure during fibrillation, while disrupting the existing $\beta$-sheets or their agglomerates during the decomposition process. Milowska et $\mathrm{al}^{94}$ observed the strong inhibition of $\alpha$-synuclein by phosphorus-containing dendrimers, depending on the dendrimer/protein ratio; the authors also found that these conjugates are effective quenchers of tyrosine fluoresecence as there will be a decrease in fluorescence intensity of intrinsic tyrosine. It is likely that the intermolecular interaction between the tyrosine hydroxyl and cationic end groups of the dendrimer are responsible for this process. It also suggests that the cationic groups of phosphorus dendrimers interact with the basic amino acid $\mathrm{N}$-terminal region of $\alpha$-synuclien, which further leads to fibril inhibition. Dendrimers used in lower concentrations are effective, while larger concentrations block the interaction of proteins and dendrimers. In addition, they interact with each other, stick together, and form larger agglomerates (dimers or oligomers).

Miura et $\mathrm{al}^{95}$ used sulfonated dendrimers and reported that they exhibited a significant inhibitory effect against aggregated amyloid $\beta$-peptide, and they also reduced $\beta$-sheet conformation. These sulfonated dendrimers displayed saccharides for effective protein and peptide affinity, and they interacted with $\mathrm{A} \beta$ peptides via electrostatic interaction with the basic amino acid residues. Inhibition can also be induced by binding the nanoparticles to the hydrophobic motif of a peptide, as reported by Kim and Lee. ${ }^{96}$ The authors reported the specific binding of fullerene to KLVFF hydrophobic patches of $A \beta$ peptide, which is a primary target for inhibition of aggregation. Insulin fibril formation is a physical process in which non-native insulin aggregates, and further deposition of insulin fibrils causes type 2 diabetes. A significant inhibition of insulin fibrils was observed by Skaat et $\mathrm{al}^{97}$ in the presence of $\gamma$ - $\mathrm{Fe}_{2} \mathrm{O}_{3} /$ PHFBA (poly(2,2,3,3,4,4,4-hept afluorobutyl acrylate)) nanoparticles. These nanoparticles slow down the transition of $\alpha$-helix to $\beta$-sheets during insulin fibril formation.

\section{Toxicity due to nanoparticles}

In spite of their production and worldwide usage, there is a serious lack of information about the adverse effects of nanoparticles on human health and environment. ${ }^{98}$ Preliminary studies show that nanoparticles can affect biological behavior at the cellular, subcellular, tissue, organ, and protein levels, but their toxicity must be overcome before the large-scale production of safe and efficient applications in the fields of pharmaceutics and in medicine can occur. ${ }^{100}$ The undesirable effects of nanoparticles may be due to their small size, chemical composition (purity, electronic properties, or crystallinity), surface structure (surface coatings - inorganic or organic), solubility, shape, and aggregation behavior. ${ }^{99}$ A large number of standardized methods are being addressed both in vitro and in vivo to assess the toxicity of these particles. ${ }^{100}$ Both in vivo as well as in vitro studies have their own advantages, as in vitro studies reduce the chance of animal handling, and it is easy to perform and can be repeated. In vitro toxicity assessments have revealed that zinc-based nanoparticles have greater toxicity when compared to copper and silver nanoparticles, while iron and titanium nanoparticles possess the least amount of toxicity. ${ }^{101,102}$ Nanoparticles possess a carcinogenic effect which is triggered by the production of reactive oxygen species (ROS) by macrophages, and also leads to DNA damage, as well as to the induction of inflammatory lesions - all of which are associated with carcinogenesis. ${ }^{103}$ Trouiller et al ${ }^{104}$ and Park et $\mathrm{al}^{105}$ reported that the generation of ROS is closely related to the oxidation of DNA and proteins in the nucleus, as well as to DNA breakage, as they found that the distribution of titanium dioxide nanoparticles induces genetic instability and DNA damage, which was consistent with the site of ROS production in the cell.

The most suitable methods used to determine the cytotoxicity of nanoparticles are MTT assay (3-[4,5-dimethylthiazol2-yl]-2-5 diphenyl tetrazolium bromide) for cell viability or cell proliferation, and lactate dehydrogenase assay, which is an indicator of cell membrane integrity. ${ }^{106}$ As nanoparticles enter the body, they come in contact with the cell membrane, which is their primary site of interaction, and induce disturbances in the lipid phosphobilayer due to changes in the local concentration of the surface charge. ${ }^{107} \mathrm{Nel}$ et $\mathrm{al}^{9}$ observed that cationic nanoparticles exhibit more toxicity than their 
anionic analogs, or than the other analogs that possess a net neutral charge but are of the same size. Polymeric particles show slightly different mechanisms, as they make holes in the cell membrane and lead to cytotoxicity by reduction in the levels of protein and lipids. ${ }^{108}$ Toxic effects have also been observed in membrane proteins, such as in ion channels that play an important role in molecular transport and transmembrane signaling. ${ }^{109}$ Silver nanoparticles, for example, are found to alter the confirmation of membrane proteins, which affect the channel opening, thus resulting in neuronal dysfunction. ${ }^{110}$ Nanomaterials can also exert their effects at genetic level, as they bind directly or indirectly to DNA and damage it via inflammatory response or by promoting oxidative stress. ${ }^{110,111}$ An extensive review of the toxicological effects of nanomaterials are described in various articles that focus on nanomaterial composition and dimension, routes of exposure and administration, translocation and distribution, and clearance from the body. ${ }^{112,113}$

\section{Conclusion}

The emerging scenario in fibril formation can be considered as the generic behavior of peptides and proteins. This leads to intermolecular $\beta$-sheet assembly, characterized by high stability and resistance to proteolysis. Such aggregation in the central nervous system, or in any of the other organs, contributes to several diseases, resulting in an intensive search for agents that prevent or inhibit aggregation, and that break and destroy the existing protein aggregates. ${ }^{114}$ Nanoparticles provide an attractive tool; as nanoparticles enter into biological fluid, a dense layer of proteins surround the nanoparticles' surface, modifying their physiochemical properties and thus their efficacy for their intended application. Control of amyloid formation via nanoparticles can be explained based on two factors: first, the surface chemistry of nanoparticles; and second, the protein's intrinsic stability. These factors determine the interaction between nanoparticles and proteins or peptides, which then leads to dual effects on the fibrillation process of amyloid proteins, and hence they act either as a microreactor or destabilizing agent, causing acceleration or retardation of amyloid formation. Since we know that fibrillation is concentration-dependent, nanoparticles induce amyloid formation by providing a high local concentration of peptides. These peptides either form amorphous aggregates, or show structural changes in the formed aggregates; in addition, inhibition may be due to the high-charge density and hydrophobic groups that are necessary to stabilize the $\alpha$-helix structure. The study of nanomaterial and biological interfaces allows us to understand the underlying mechanisms involved in nanotoxicity, and these properties provide a model through which to distinguish cell states, while offering a new possibility to exploit these properties for nanotoxicity research. This is especially true since the effects of nanomaterials on cellular biophysical responses have only recently garnered attention. Currently, nanotechnology has reached a remarkable stage, where $A \beta$ aggregation both in the brain and in peripheral circulation can be manipulated; however, some important questions remain to be answered before engaging in further research and clinical investigations. These include questions surrounding the efficiency of the nanoparticle system, the validation of symptom alleviation in representative Alzheimer's disease models in vivo, and the employment of US Food and Drug Administration-approved molecules for nanoparticle formulation. Moreover, the non-invasive administration of nanoparticles must be considered for repeated and prolonged therapeutic purposes. Although nanotechnology is expected to have a huge impact against various neurodegenerative diseases, as well as in drug delivery, imaging agents, cancer therapies, and in various applications in the antiseptic industry, the food industry, and pharmaceutics, a crucial gap has yet to be filled concerning the elucidation of nanotechnology etiology, for which a great deal of effort is still required.

\section{Disclosure}

The authors report no conflicts of interest in this work.

\section{References}

1. Salata OV. Applications of nanoparticles in biology and medicine. J Nanobiotechnology. 2004;2(1):3.

2. Burke KA, Yates EA, Legleiter J. Biophysical insights into how surfaces, including lipid membranes, modulate protein aggregation related to neurodegeneration. Front Neurol. 2013;4:17.

3. Sipe JD, Benson MD, Buxbaum JN, et al. Amyloid fibril protein nomenclature: 2010 recommendations from the nomenclature committee of the International Society of Amyloidosis. Amyloid. 2010;17(3-4):101-104.

4. Fink AL. Protein aggregation: folding aggregates, inclusion bodies and amyloid. Fold Des. 1998;3(1):R9-R23.

5. Fowler DM, Koulov AV, Balch WE, Kelly JW. Functional amyloid - from bacteria to humans. Trends Biochem Sci. 2007;32(5):217-224.

6. Stefani M, Dobson CM. Protein aggregation and aggregate toxicity: new insights into protein folding, misfolding diseases and biological evolution. J Mol Med (Berl). 2003;81(11):678-699.

7. Naiki H, Hashimoto N, Suzuki S, Kimura H, Nakakuki K, Gejyo F. Establishment of a kinetic model of dialysis-related amyloid fibril extension in vivo. Amyloid. 1997;4(4):223-232.

8. Goy-López S, Juárez J, Alatorre-Meda M, et al. Physicochemical characteristics of protein-NP bioconjugates: the role of particle curvature and solution conditions on human serum albumin conformation and fibrillogenesis inhibition. Langmuir. 2012;28(24):9113-9126.

9. Nel AE, Mädler L, Velegol D, et al. Understanding biophysicochemical interactions at the nano-bio interface. Nat Mater. 2009;8(7): 543-557. 
10. Hill SE, Miti T, Richmond T, Muschol M. Spatial extent of charge repulsion regulates assembly pathways for lysozyme amyloid fibrils. PLoS One. 2011;6(4):e18171.

11. Raccosta S, Martorana V, Manno M. Thermodynamic versus conformational metastability in fibril-forming lysozyme solutions. J Phys Chem B. 2012;116(40):12078-12087.

12. Manno M, Mauro M, Craparo EF, et al. Kinetics of different processes in human insulin amyloid formation. $J$ Mol Biol. 2007;366(1):258-274.

13. Andersen CB, Yagi H, Manno M, et al. Branching in amyloid fibril growth. Biophys J. 2009;96(4):1529-1536.

14. Knight JD, Miranker AD. Phospholipid catalysis of diabetic amyloid assembly. J Mol Biol. 2004;341(5):1175-1187.

15. Lu JR, Perumal S, Powers ET, Kelly JW, Webster JR, Penfold J. Adsorption of beta-hairpin peptides on the surface of water: a neutron reflection study. J Am Chem Soc. 2003;125(13):3751-3757.

16. Linse $\mathrm{S}$, Cabaleiro-Lago C, Xue WF, et al. Nucleation of protein fibrillation by nanoparticles. Proc Natl Acad Sci US A. 2007;104(21):8691-8696.

17. Wu WH, Sun X, Yu YP, et al. TiO2 nanoparticles promote beta-amyloid fibrillation in vitro. Biochem Biophys Res Commun. 2008;373(2): 315-318.

18. Philo JS, Arakawa T. Mechanisms of protein aggregation. Curr Pharm Biotechnol. 2009;10(4):348-351.

19. Abbasi S, Paul A, Shao W, Prakash S. Cationic albumin nanoparticles for enhanced drug delivery to treat breast cancer: preparation and in vitro assessment. J Drug Deliv. 2012;2012:686108.

20. Fei L, Perrett S. Effect of nanoparticles on protein folding and fibrillogenesis. Int J Mol Sci. 2009;10(2):646-655.

21. Cabaleiro-Lago C, Szczepankiewicz O, Linse S. The effect of nanoparticles on amyloid aggregation depends on the protein stability and intrinsic aggregation rate. Langmuir. 2012;28(3):1852-1857.

22. Katz E, Willner I. Biomolecule-functionalized carbon nanotubes: applications in nanobioelectronics. Chemphyschem. 2004;5(8): 1084-1104.

23. Pasquasto L, Pengo P, Scrimin P. Biological and biomimetic applications of nanoparticles. In: Rotello VM, editor. Nanoparticles: Building Blocks for Nanotechnology. New York, NY: Springer Science + Business Media, Inc; 2004:251-282.

24. Sebak S, Mirzaei M, Malhotra M, Kulamarva A, Prakash S. Human serum albumin nanoparticles as an efficient noscapine drug delivery system for potential use in breast cancer: preparation and in vitro analysis. Int J Nanomedicine. 2010;5:525-532.

25. Kreuter J. Nanoparticulate systems in drug delivery and targeting. J Drug Target. 1995;3(3):171-173.

26. Delehanty JB, Boeneman K, Bradburne CE, Robertson K, Bongard JE, Medintz IL. Peptides for specific intracellular delivery and targeting of nanoparticles: implications for developing nanoparticle-mediated drug delivery. Ther Deliv. 2010;1(3):411-433.

27. Yao N, Xiao W, Wang X, et al. Discovery of targeting ligands for breast cancer cells using the one-bead-one-compound combinatorial method. J Med Chem. 2009;52(1):126-133.

28. Takahashi T, Mihara H. Peptide and protein mimetics inhibiting amyloid beta-peptide aggregation. Acc Chem Res. 2008;41(10):1309-1318.

29. Sato J, Takahashi T, Oshima H, Matsumura S, Mihara H. Design of peptides that form amyloid-like fibrils capturing amyloid beta1-42 peptides. Chemistry. 2007;13(27):7745-7752.

30. Li M, Xu C, Wu L, Ren J, Wang E, Qu X. Self-assembled peptidepolyoxometalate hybrid nanospheres: two in one enhances targeted inhibition of amyloid $\beta$-peptide aggregation associated with Alzheimer's disease. Small. 2013;9(20);3455-3461.

31. Jarmuła A, Stępkowski D. The $\beta$-sheet breakers and $\pi$-stacking. J Pept Sci. 2013;19(6):345-349.

32. Todorova N, Yeung L, Hung A, Yarovsky I. "Janus" cyclic peptides: a new approach to amyloid fibril inhibition? PLoS One. 2013;8(2): e57437.

33. Liu Z, Gao X, Kang T, et al. B6 peptide-modified PEG-PLA nanoparticles for enhanced brain delivery of neuroprotective peptide. Bioconjug Chem. 2013;24(6):997-1007.
34. Weber C, Coester C, Kreuter J, Langer K. Desolvation process and surface characterisation of protein nanoparticles. Int J Pharm. 2000;194(1):91-102.

35. Schwick HG, Heide K. Immunochemistry and immunology of collagen and gelatin. Bibl Haematol. 1969;33:111-125.

36. Coester C, Nayyar P, Samuel J. In vitro uptake of gelatin nanoparticles by murine dendritic cells and their intracellular localisation. Eur $J$ Pharm Biopharm. 2006;62(3):306-314.

37. Vandervoort J, Ludwig A. Preparation and evaluation of drug-loaded gelatin nanoparticles for topical ophthalmic use. Eur J Pharm Biopharm. 2004;57(2):251-261.

38. Azarmi S, Huang Y, Chen H, et al. Optimization of a two-step desolvation method for preparing gelatin nanoparticles and cell uptake studies in 143B osteosarcoma cancer cells. J Pharm Pharm Sci. 2006;9(1):124-132.

39. Jahanshahi M, Sanati MH, Babaei Z. Optimization of parameters for the fabrication of gelatin nanoparticles by the Taguchi robust design method. J Appl Stat. 2008;35(12):1345-1353.

40. Kuntworbe N, Al-Kassas R. Design and in vitro haemolytic evaluation of cryptolepine hydrochloride-loaded gelatine nanoparticles as a novel approach for the treatment of malaria. AAPS Pharm Sci Tech. 2012;13(2):568-581.

41. Riche M, Williams TN. Apparent digestible protein, energy and amino acid availability of three plant proteins in Florida pompano, Trachinotus carolinus L. in seawater and low-salinity water. Aquaculture Nutrition. 2009;16(3):223-230.

42. Arangoa MA, Ponchel G, Orecchioni AM, Renedo MJ, Duchêne D, Irache JM. Bioadhesive potential of gliadin nanoparticulate systems. Eur J Pharm Sci. 2000;11(4):333-341.

43. Elzoghby AO, Samy WM, Elgindy NA. Albumin-based nanoparticles as potential controlled release drug delivery systems. J Control Release. 2012;157(2):168-182.

44. Irache JM, Merodio M, Arnedo A, Camapanero MA, Mirshahi M, Espuelas S. Albumin nanoparticles for the intravitreal delivery of anticytomegaloviral drugs. Mini Rev Med Chem. 2005;5(3):293-305.

45. Geny B, Mettauer B, Muan B, et al. Safety and efficacy of a new transpulmonary echo contrast agent in echocardiographic studies in patients. J Am Coll Cardiol. 1993;22(4):1193-1198.

46. Ibrahim NK, Desai N, Legha S, et al. Phase I and pharmacokinetic study of ABI-007, a Cremophor-free, protein-stabilized, nanoparticle formulation of paclitaxel. Clin Cancer Res. 2002;8(5): 1038-1044

47. Jahanshahi M, Babaei Z. Protein nanoparticle: a unique system as drug delivery vehicles. African Journal of Biotechnology. 2008;7(25): 4926-4934.

48. Tauran Y, Brioude A, Coleman AW, Rhimi M, Kim B. Molecular recognition by gold, silver and copper nanoparticles. World J Biol Chem. 2013;4(3):35-63

49. Rao JP, Geckeler KE. Polymer nanoparticles: preparation techniques and size-control parameters. Prog Polym Sci. 2011;36(7):887-913.

50. Scheffel U, Rhodes BA, Natarajan TK, Wagner HN. Albumin microspheres for study of the reticuloendothelial system. J Nucl Med. 1972;13(7):498-503

51. Gao ZH, Shukla AJ, Johnson JR, Crowley WR. Controlled release of a contraceptive steroid from biodegradable and injectable gel formulations: in vitro evaluation. Pharm Res. 1995;12(6): 857-863

52. Marty JJ, Oppenheim RC, Speiser P. Nanoparticles - a new colloidal drug delivery system. Pharm Acta Helv. 1978;53(1):17-23.

53. Lin W, Coombes AG, Davies MC, Davis SS, Illum L. Preparation of sub$100 \mathrm{~nm}$ human serum albumin nanospheres using a $\mathrm{pH}$-coacervation method. J Drug Target. 1993;1(3):237-243.

54. Coester CJ, Langer K, van Briesen H, Kreuter J. Gelatin nanoparticles by two step desolvation - a new preparation method, surface modifications and cell uptake. J Microencapsul. 2000;17(2):187-193.

55. Turkevich J, Stevenson PC, Hillier J. A study of the nucleation and growth processes in the synthesis of colloidal gold. Discuss Faraday Soc. 1951;11:55-75. 
56. Benavente E, Lozano H, González G. Fabrication of copper nanoparticles: advances in synthesis, morphology control, and chemical stability. Recent Pat Nanotechnol. 2013;7(2):108-132.

57. Bae DR, Han WS, Lim JM, et al. Lysine-functionalized silver nanoparticles for visual detection and separation of histidine and histidinetagged proteins. Langmuir. 2010;26(3):2181-2185.

58. Astete CE, Sabliov CM. Synthesis and characterization of PLGA nanoparticles. J Biomater Sci Polym Ed. 2006;17(3):247-289.

59. Rao CN, Ramakrishna Matte HS, Voggu R, Govindaraj A. Recent progress in the synthesis of inorganic nanoparticles. Dalton Trans. 2012;41(17):5089-5120.

60. Wei X, Wang W, Chen K. Preparation and characterization of ZnS: Tb,Gd and $\mathrm{ZnS}$ : Er,Yb,Gd nanoparticles for bimodal magnetic-fluorescent imaging. Dalton Trans. 2013;42(5):1752-1579.

61. Crespo L, Sanclimens G, Pons M, Giralt E, Royo M, Albericio F. Peptide and amide bond-containing dendrimers. Chem Rev. 2005;105(5): 1663-1681.

62. Desai MP, Labhasetwar V, Walter E, Levy RJ, Amidon GL. The mechanism of uptake of biodegradable microparticles in Caco-2 cells is size dependent. Pharm Res. 1997;14(11):1568-1573.

63. Zauner W, Farrow NA, Haines AM. In vitro uptake of polystyrene microspheres: effect of particle size, cell line and cell density. J Control Release. 2001;71(1):39-51.

64. Babaei Z, Jahanshahi M, Sanati MH. Fabrication and evaluation of gelatin nanoparticles for delivering of anti-cancer drug. International Journal of Nanoscience and Nanotechnology. 2008;4(1):23-30.

65. Powers KW, Brown SC, Krishna VB, Wasdo SC, Moudgil BM, Roberts SM. Research strategies for safety evaluation of nanomaterials. Part VI. Characterization of nanoscale particles for toxicological evaluation. Toxicol Sci. 2006;90(2):296-303.

66. Brar SK, Verma M. Measurement of nanoparticles by light-scattering techniques. TrAC Trends in Analytical Chemistry. 2011;30(1):4-17.

67. Khlebtsov BN, Khlebtsov NG. On the measurement of gold nanoparticle sizes by the dynamic light scattering method. Colloid Journal. 2011;73(1):118-127.

68. Klang V, Valenta C, Matsko NB. Electron microscopy of pharmaceutical systems. Micron. 2013;44:45-74.

69. Tracy JB, Crowe MC, Parker JF, et al. Electrospray ionization mass spectrometry of uniform and mixed monolayer nanoparticles: Au25[S(CH2)2Ph]18 and Au25[S(CH2)2Ph]18-x(SR)x. J Am Chem Soc. 2007;129(51):16209-16215.

70. Ho CS, Lam CW, Chan MH, et al. Electrospray ionisation mass spectrometry: principles and clinical applications. Clin Biochem Rev. 2003;24(1):3-12.

71. Clogston JD, Patri AK. Zeta potential measurement. Methods Mol Biol. 2011;697:63-70.

72. Vertegel AA, Siegel RW, Dordick JS. Silica nanoparticle size influences the structure and enzymatic activity of adsorbed lysozyme. Langmuir. 2004;20(16):6800-6807.

73. Sear RP. Nucleation: theory and applications to protein solutions and colloidal suspensions. J Phys Condens Matter. 2007;19(3): 033101.

74. Auer S, Trovato A, Vendruscolo M. A condensation-ordering mechanism in nanoparticle-catalyzed peptide aggregation. PLoS Comput Biol. 2009;5(8):e1000458

75. Lynch I, Dowson KA. Protein-nanoparticle interactions. Nano Today. 2008;3(1-2):40-47.

76. Nielsen L, Khurana R, Coats A, et al. Effect of environmental factors on the kinetics of insulin fibril formation: elucidation of the molecular mechanism. Biochemistry. 2001;40(20):6036-6046.

77. Colvin VL, Kulinowski KM. Nanoparticles as catalysts for protein fibrillation. Proc Natl Acad Sci U S A. 2007;104(21):8679-8680.

78. Baker SE, Cai W, Lasseter TL, Weidkamp KP, Hamers RJ. Covalently bonded adducts of deoxyribonucleic acid (DNA) oligonucleotides with single-wall carbon nanotubes: synthesis and hybridization. Nano Lett. 2002;2(12):1413-1417.

79. Rocha S, Thünemann AF, Pereira Mdo C, Coelho M, Möhwald H, Brezesinski G. Influence of fluorinated and hydrogenated nanoparticles on the structure and fibrillogenesis of amyloid beta-peptide. Biophys Chem. 2008;137(1):35-42.
80. Jones CF, Campbell RA, Brooks AE, et al. Cationic PAMAM dendrimers aggressively initiate blood clot formation. ACS Nano. 2012;6(11):9900-9910.

81. Tang Z, Zhang Z, Wang Y, Glotzer SC, Kotov NA. Self-assembly of CdTe nanocrystals into free-floating sheets. Science. 2006;314(5797): 274-278.

82. Bellova A, Bystrenova E, Koneracka M, et al. Effect of $\mathrm{Fe}(3) \mathrm{O}(4)$ magnetic nanoparticles on lysozyme amyloid aggregation. Nanotechnology. 2010;21(6):065103.

83. LeVine $H$. Thioflavine $T$ interaction with amyloid $\beta$-sheet structures. Amyloid. 1995;2(1):1-6.

84. Arnaudov LN, de Vries R. Thermally induced fibrillar aggregation of hen egg white lysozyme. Biophys J. 2005;88(1):515-526.

85. Heldt CL, Zhang S, Belfort G. Asymmetric amyloid fibril elongation: a new perspective on a symmetric world. Proteins. 2011;79(1):92-98.

86. Chiti F, Dobson CM. Protein misfolding, functional amyloid, and human disease. Annu Rev Biochem. 2006;75:333-366.

87. Lee CC, Nayak A, Sethuraman A, Belfort G, McRae GJ. A threestage kinetic model of amyloid fibrillation. Biophys J. 2007;92(10): 3448-3458.

88. Cabaleiro-Lago C, Quinlan-Pluck F, Lynch I, Dawson KA, Linse S. Dual effect of amino modified polystyrene nanoparticles on amyloid $\beta$ protein fibrillation. ACS Chem Neurosci. 2010;1(4):279-287.

89. Cabaleiro-Lago C, Quinlan-Pluck F, Lynch I, et al. Inhibition of amyloid beta protein fibrillation by polymeric nanoparticles. J Am Chem Soc. 2008;130(46):15437-15443.

90. Skaat H, Chen R, Grinberg I, Margel S. Engineered polymer nanoparticles containing hydrophobic dipeptide for inhibition of amyloid- $\beta$ fibrillation. Biomacromolecules. 2012;13(9):2662-2670.

91. Milowska K, Malachowska M, Gabryelak T. PAMAM G4 dendrimers affect the aggregation of $\alpha$-synuclein. Int J Biol Macromol. 2011;48(5):742-746.

92. Klajnert B, Cortijo-Arellano M, Cladera J, Bryszewska M. Influence of dendrimer's structure on its activity against amyloid fibril formation. Biochem Biophys Res Commun. 2006;345(1):21-28.

93. Rekas A, Lo V, Gadd GE, Cappai R, Yun SI. PAMAM dendrimers as potential agents against fibrillation of alpha-synuclein, a Parkinson's disease-related protein. Macromol Biosci. 2009;9(3):230-238.

94. Milowska K, Gabryelak T, Bryszewska M, Caminade AM, Majoral JP. Phosphorus-containing dendrimers against $\alpha$-synuclein fibril formation. Int J Biol Macromol. 2012;50(4):1138-1143.

95. Miura Y, Onogi S, Fukuda T. Syntheses of sulfo-glycodendrimers using click chemistry and their biological evaluation. Molecules. 2012;17(10):11877-11896.

96. Kim JE, Lee M. Fullerene inhibits beta-amyloid peptide aggregation. Biochem Biophys Res Commun. 2003;303(2):576-579.

97. Skaat H, Belfort G, Margel S. Synthesis and characterization of fluorinated magnetic core-shell nanoparticles for inhibition of insulin amyloid fibril formation. Nanotechnology. 2009;20(22):225106.

98. Savolainen K, Alenius H, Norppa H, Pylkkänen L, Tuomi T, Kasper G. Risk assessment of engineered nanomaterials and nanotechnologies $-\mathrm{a}$ review. Toxicology. 2010;269(2-3):92-104.

99. Nel A, Xia T, Mädler L, Li N. Toxic potential of materials at the nanolevel. Science. 2006;311(5761):622-627.

100. Schrand AM, Rahman MF, Hussain SM, Schlager JJ, Smith DA, Syed AF. Metal-based nanoparticles and their toxicity assessment. Wiley Interdiscip Rev Nanomed Nanobiotechnol. 2010;2(5):544-568.

101. Wang B, Feng WY, Wang TC, et al. Acute toxicity of nano- and microscale zinc powder in healthy adult mice. Toxicol Lett. 2006;161(2): 115-123.

102. Rothen-Rutishauser B, Grass RN, Blank F, et al. Direct combination of nanoparticle fabrication and exposure to lung cell cultures in a closed setup as a method to simulate accidental nanoparticle exposure of humans. Environ Sci Technol. 2009;43(7):2634-2640.

103. Loo SC, Moore T, Banik B, Alexis F. Biomedical applications of hydroxyapatite nanoparticles. Curr Pharm Biotechnol. 2010;11(4): $333-342$. 
104. Trouiller B, Reliene R, Westbrook A, Solaimani P, Schiestl RH. Titanium dioxide nanoparticles induce DNA damage and genetic instability in vivo in mice. Cancer Res. 2009;69(22):8784-8789.

105. Park EJ, Yi J, Chung KH, Ryu DY, Choi J, Park K. Oxidative stress and apoptosis induced by titanium dioxide nanoparticles in cultured BEAS-2B cells. Toxicol Lett. 2008;180(3):222-229.

106. Lu S, Duffin R, Poland C, et al. Efficacy of simple short-term in vitro assays for predicting the potential of metal oxide nanoparticles to cause pulmonary inflammation. Environ Health Perspect. 2009;117(2):241-247.

107. Arvizo RR, Miranda OR, Thompson MA, et al. Effect of nanoparticle surface charge at the plasma membrane and beyond. Nano Lett. 2010;10(7):2543-2548.

108. Verma A, Uzun O, Hu Y, et al. Surface-structure-regulated cellmembrane penetration by monolayer-protected nanoparticles. Nat Mater. 2008;7(7):588-595.

109. Liu Z, Ren G, Zhang T, Yang Z. Action potential changes associated with the inhibitory effects on voltage-gated sodium current of hippocampal CA1 neurons by silver nanoparticles. Toxicology. 2009;264(3):179-184.
110. Ng KW, Khoo SP, Heng BC, et al. The role of the tumor suppressor p53 pathway in the cellular DNA damage response to zinc oxide nanoparticles. Biomaterials. 2011;32(32):8218-8225.

111. Sablina AA, Budanov AV, Ilyinskaya GV, Agapova LS, Kravchenko JE, Chumakov PM. The antioxidant function of the $\mathrm{p} 53$ tumor suppressor. Nat Med. 2005;11(12):1306-1313.

112. Soenen SJ, Rivera-Gil P, Montenegro JM, Parak WJ, De Smedt SC, Braeckmans K. Cellular toxicity of inorganic nanoparticles: common aspects and guidelines for improved nanotoxicity evaluation. Nano Today. 2011;6(5):446-465.

113. Unfried K, Albrecht C, Klotz LO, Von Mikecz A, Grether-Beck S, Schins RPF. Cellular responses to nanoparticles: target structures and mechanisms. Nanotoxicology. 2007;1(1):52-71.

114. Cedervall T, Lynch I, Lindman S, et al. Understanding the nanoparticle-protein corona using methods to quantify exchange rates and affinities of proteins for nanoparticles. Proc Natl Acad Sci U S A. 2007;104(7):2050-2055.
International Journal of Nanomedicine

\section{Publish your work in this journal}

The International Journal of Nanomedicine is an international, peerreviewed journal focusing on the application of nanotechnology in diagnostics, therapeutics, and drug delivery systems throughout the biomedical field. This journal is indexed on PubMed Central, MedLine, CAS, SciSearch $\AA$, Current Contents ${ }^{\circledR} /$ Clinical Medicine,

\section{Dovepress}

Journal Citation Reports/Science Edition, EMBase, Scopus and the Elsevier Bibliographic databases. The manuscript management system is completely online and includes a very quick and fair peer-review system, which is all easy to use. Visit http://www.dovepress.com/ testimonials.php to read real quotes from published authors. 